\title{
Peningkatan Kualitas Pegawai melalui Program Autocad : Pendekatan Social Exchange Theory
}

\author{
Riza Bahtiar Sulistyan*1 \\ ${ }^{1}$ STIE Widya Gama Lumajang \\ *e-mail: rizabahtiars@gmail.com ${ }^{1}$
}

\begin{abstract}
The existence of technology in the world of work is very necessary in the current era and will make a worker more quickly complete his work. The problem that occurs is the lack of knowledge to operate an autocad program that can accelerate the completion of work, especially related to development planning. Training is needed to improve employee knowledge and abilities. The method used in the form of stages of preparation, implementation, and evaluation as well as implementation. The results show that the training activities are in accordance with what is expected and in accordance with the application of social exchange theory, namely the perceived benefits of the organization for giving employees the opportunity to attend training. An assessment of the success of the training has shown results that are above predetermined standards. Although it is not yet optimal, training activities can provide benefits felt by the organization.
\end{abstract}

Keywords: training, employee, autocad program, social exchange theory

\section{Abstrak}

Keberadaan teknologi dalam dunia kerja sangat diperlukan di era sekarang dan akan membuat seorang pekerja semakin cepat menyelesaikan pekerjaanya. Permasalahan yang terjadi yaitu kurangnya pengetahuan untuk mengoperasikan program autocad yang dapat mempercepat penyelesaian pekerjaan terutama yang berhubungan dengan perencanaan pembangunan. Perlu dilakukan pelatihan agar pengetahuan dan kemampuan karyawan meningkat. Metode yang dilakukan berupa tahap persiapan, pelaksanaan, dan evaluasi serta penerapan. Hasil menunjukkan bahwa kegiatan pelatihan telah sesuai dengan yang diharapkan dan sesuai dengan penerapan social exchange theory yaitu adanya timbal balikyang dirasakan organisasi atas pemberian kesempatan karyawan untuk mengikuti pelatihan. Penilaian atas keberhasilan pelatihan telah menunjukkan hasil di atas standar yang sudah ditentukan. Meskipun belum optimal, namun kegiatan pelatihan mampu memberikan manfaat yang dirasakan oleh pihak organisasi.

Kata kunci: pelatihan, karyawan, program autocad, social exchange theory

\section{PENDAHULUAN}

Diera teknologi seperti sekarang perlu adanya upaya-upaya untuk membuat seorang pegawai semakin berkembang dengan beradaptasi dari perubahan teknologi. Hal ini dapat diwujudkan melalui sistem manajemen retensi (Sulistyan, Ermawati, Hidayat, Lukiana, \& Kasno, 2019). Salah satunya dengan program pelatihan dan pendampingan. Perlu adanya proses pelatihan dan pendampingan dalam meningkatkan perilaku pegawai yang lebih kreatif (Mokhber, Khairuzzaman, \& Vakilbashi, 2018). Telah terbukti bahwa kegiatan pelatihan yang dapat menjadikan seseorang untuk lebih kreatif diantaranya pelatihan pembelajaran komputer (Dharmawati, Lubis, \& Liza, 2020), pelatihan aplikasi data (Sandy et al., 2020), pelatihan bahasa inggris (Ishak \& Mulyanah, 2020; Warman, Mardian, Suryani, Fista, \& Irwan, 2019), pelatihan pengelolaan website (Sulistyan, 2017), dan pelatihan-pelatihan yang lainnya. Adanya pelatihan berbasis komputer dapat dirasakan manfaatnya pasca pelatihan seperti keterampilan dan kemampuan yang meningkat (Dharmawati et al., 2020). Didukung dengan pelatihan aplikasi data yang dapat mempermudah dalam mengerjakan pekerjaan (Sandy et al., 2020).

Peraturan Menteri dalam Negeri Republik Indonesia nomor 4 tahun 2019 tentang tata cara peran masyarakat dalam perencanaan tata ruang di daerah disebutkan dalam pasal 7 bahwa perangkat daerah melaksanakan persiapan penyusunan rencana tata ruang dan hasil pelaksanaan penyusunan rencana tata ruang tersebut dipublikasikan kepada masyarakat. Berkaitan dengan rencana tata ruang daerah masih terdapat beberapa kendala salah satunya di Kabupaten Lumajang tepatnya pada karyawan kontrak Dinas Pekerjaan Umum dan Tata Ruang Unit 
Pelaksana Teknis (UPT) Yosowilangun. Dari hasil survei awal, terdapat kendala atau permasalahan terkait dengan perencanaan pembangunan proyek yang menggunakan program autocad. Permasalahan tersebut berkaitan dengan kurangnya pengetahuan penggunaan program yang akan mempercepat penyelesaian dalam perencanaan pembangunan.

Berkaitan dengan perencanaan pembangunan proyek, memang diperlukan sebuah keahlian khusus seperti pengoperasian program autocad. Tidak hanya memerlukan dalam bentuk 2 dimensi namun juga dalam bentuk 3 dimensi (Ramadhan, 2016). Adanya pelatihan perencanaan pembangunan dengan program autocad ini diharapkan akan dapat meningkatkan keterampilan peserta yang terdiri dari karyawan kontrak dan pihak yang terlibat dibidang pembangunan. Pelatihan ini sangat penting untuk dilakukan dan dapat memberikan beberapa manfaat penting kepada karyawan. Manfaat adanya pelatihan yaitu meningkatkan pengetahuan (Yanti, Zainuri, \& Megasari, 2019), meningkatkan kemampuan dan keterampilan (Dharmawati et al., 2020; Wen, Huang, \& Hou, 2019), peningkatan motivasi, kepercayaan, dan kompetensi (Ishak \& Mulyanah, 2020), kemudahan dalam menyelesaikan pekerjaan (Sandy et al., 2020), kepuasan kerja meningkat (Wen et al., 2019), perilaku kerja yang inovatif (Mishra, Bhatnagar, Gupta, \& Wadsworth, 2019), serta terbentuknya kesadaran peserta akan pentingnya pelatihan dan pendampingan (Sulistyan, 2017).

Pendekatan yang dilakukan melalui social exchange theory yaitu organisasi memberikan sesuatu yang bernilai kepada karyawan, sebaliknya karyawan akan memberikan yang terbaik untuk organisasi (Blau (1964) dalam Sulistyan, Ermawati, et al., 2019). Teori ini telah terbukti digunakan untuk menjelaskan adanya program pelatihan dan dampak positif bagi organisasi (de Grip, Fouarge, Montizaan, \& Schreurs, 2020; Pham, Vo-Thanh, Shahbaz, Duc Huynh, \& Usman, 2020; Sok, Blomme, Ruiter, Tromp, \& Lub, 2018). Dalam hal ini, UPT Yosowilangun memberikan kesempatan mengikuti pelatihan kepada karyawannya dengan harapan kemampuan karyawan akan meningkat dan memberikan kontribusi bagi lembaga.

\section{METODE}

Metode yang digunakan berupa data kuantitatif, dengan memberikan skor penilaian terhadap keberhasilan kegiatan pelatihan. Adapun tahap yang dilakukan meliputi tahap persiapan, pelaksanaan, dan evaluasi (Sulistyan, Setyobakti, \& Darmawan, 2019). Tahap persiapan meliputi survei awal untuk mengindentifikasi permasalahan dan menentukan metode yang tepat. Tahap pelaksanaan yaitu melaksanakan kegiatan yang telah direncanakan. Tahap evaluasi dilakukan untuk memberikan umpan balik dan memberikan evaluasi atas apa yang sudah dilaksanakan. Evaluasi ketercapaian dapat dilihat dari adanya peningkatan keterampilan dan kemampuan dalam pengoperasian program autocad. Penilaian dilakukan dalam 4 kriteria mulai dari kecepatan, ketelitian, pemahaman fitur, dan penerapan dalam perencanaan pembangunan. Masing-masing kriteria diberikan bobot skor 25 sehingga total keberhasilan 100 . Adapun batas minimal keberhasilan adalah dengan bobot 75 .

\section{HASIL DAN PEMBAHASAN}

\subsection{Hasil}

Hasil dari kegiatan pelatihan ini dimulai dari tahap persiapan. Pada tahap ini diperoleh hasil dari adanya identifikasi masalah yaitu perlunya pelatihan guna mendukung kelancaran dalam pekerjaan terutama dalam bidang perencanaan pembangunan. Setelah dilakukan diskusi dengan beberapa pihak yang terlibat di Dinas Pekerjaan Umum dan Tata Ruang Unit Pelaksana Teknis (UPT) Yosowilangun, diperoleh metode yang tepat untuk melaksanakan kegiatan pelatihan. Pelatihan tersebut berupa kegiatan pengenalan dan sekaligus praktek program autocad. Target peserta dari kegiatan pelatihan ini yaitu karyawan kontrak. 


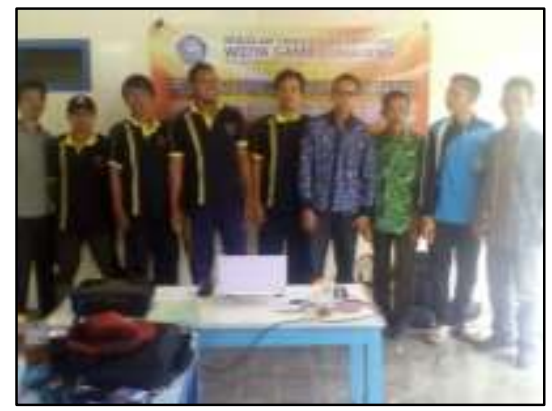

Gambar 1. Karyawan Kontrak UPT Yosowilangun

Tahap pelaksanaan memperoleh hasil yaitu berupa kegiatan pelatihan yang diadakan di kantor UPT Yowilangun. Dalam tahap ini peserta dikenalkan terlebih dahulu tentang program autocad, fitur-fitur, fungsi dan kegunaan, serta penerapan dalam dunia nyata. Kegiatan praktek dilakukan setelah peserta benar-benar memahami fungsi dan kegunaan dari program tersebut. Penerapan dari program tersebut ke dunia nyata dengan meninjau lokasi perencanaan proyek yang akan dilakukan pembangunan.
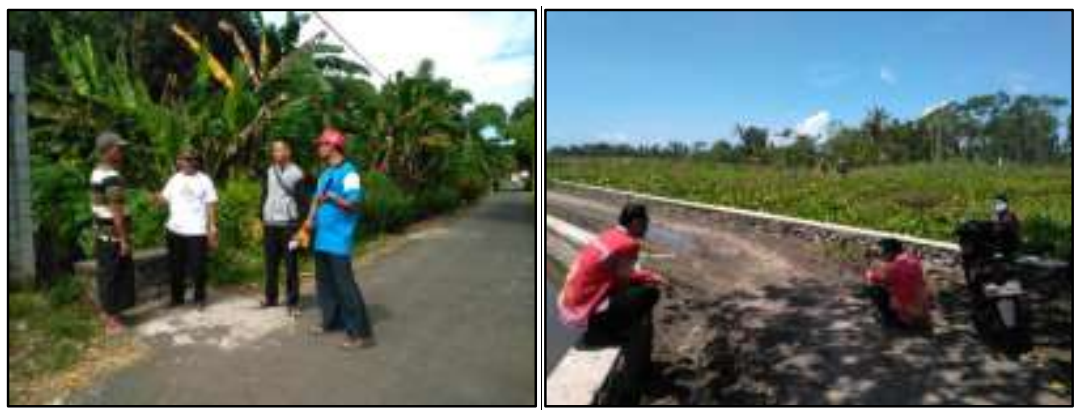

Gambar 2. Praktik Lapangan untuk digambar pada Program Autocad

Tahap terakhir yaitu evaluasi yang dilakukan dengan memberikan umpan balik peserta dan dilakukan penilaian keberhasilan atas pelatihan yang telah dilakukan. Umpan balik dilakukan dengan melakukan interview kepada peserta mengenai pemahaman materi yang telah disampaikan. Penilaian dilakukan dengan memberikan skor atas apa yang telah dikerjakan. Adapun rata-rata penilaian sebagai berikut:

Tabel 1. Hasil Rata-rata Penilaian Peserta Pelatihan

\begin{tabular}{llcll}
\hline No & Aspek Penilaian & Skor Rata-rata & \multicolumn{2}{c}{ Keterangan } \\
\hline 1 & Kecepatan & 15 & $\begin{array}{l}\text { Kurangnya kecepatan dalam } \\
\text { pengoperasian }\end{array}$ \\
2 & Ketelitian & 20 & $\begin{array}{l}\text { Kurang teliti dalam perhitungan } \\
\text { skala }\end{array}$ \\
3 & Pemahaman Fitur & 20 & $\begin{array}{l}\text { Masih belum memahami fitur-fitur } \\
\text { secara menyeluruh } \\
\text { Penerapan dalam pembangunan } \\
\text { sudah optimal }\end{array}$ \\
\hline & Penerapan & 25 & & \\
\hline
\end{tabular}




\subsection{Pembahasan}

Kegiatan pelatihan ini sudah sesuai dengan apa yang diharapkan. Hasil pelatihan ini sesuai dengan social exchange theory, dimana pihak UPT Yosowilangun merasakan manfaat dari adanya pelatihan program autocad. Social exchange theory telah membuktikan bahwa adanya manfaat dari program pelatihan untuk kemajuan organisasi (Blau (1964) dalam Sulistyan, Ermawati, et al., 2019). Pihak organisasi telah memberikan kesempatan yang besar kepada karyawan kontraknya untuk mengikuti pelatihan, dan imbalan yang diberikan dari pelatihan tersebut yaitu kemampuan dari karyawan yang meningkat sehingga organisasi menjadi semakin berkembang. Karyawan yang menjadi peserta pelatihan dapat dimanfaatkan organisasi untuk program perencanaan pembangunan seperti yang telah diharapkan.

Identifikasi masalah yang telah dilakukan mampu ditangani dengan program pelatihan. Permasalahan terkait kurangnya pemahaman dan kemampuan dalam pengoperasian program autocad dapat terselesaikan dengan kegiatan pelatihan dan praktek langsung ke lokasi pembangunan. Pemahaman baik mengenai fitur-fitur yang ada di dalam program, serta fungsi dan kegunaannya dapat dipahami setelah peserta melakukan praktek langsung untuk mengoperasikannya. Setelah dilakukan praktek, tahap evaluasi perlu dilakukan untuk memberikan umpan balik serta penilaian keberhasilan dari pelatihan. Penilaian sudah memenuhi standar yang telah ditentukan dengan nilai lebih dari 75 . Namun masih belum dapat maksimal dengan hanya mencapai nilai rata-rata 80.

Penilaian yang masih belum optimal disebabkan oleh beberapa faktor. Aspek kecepatan terjadi kendala pada pengoperasian yang memang peserta masih belum mempunyai pengalaman dan baru mengenal program autocad. Selain itu dari tingkat bahasa juga mempengaruhi kecepatan karena keseluruhan isi dari fitur-fitur yang disediakan dalam program tidak menggunakan bahasa Indonesia. Aspek ketelitian yang menjadi faktor penghambat adalah kurangnya ketelitian dari peserta. Sehingga ketika dilakukan review masih kurang sesuai dengan keadaan di lokasi. Kurangnya ketelitian meliputi kurangnya teliti dalam melakukan pengukuran dilapangan dan dilakukan skala dalam gambar. Aspek pemahaman fitur juga belum optimal yang disebabkan tata letak yang masih belum mengingat keberadaannya. Aspek penerapan sudah menunjukkan hasil yang optimal yaitu menerapkan hasil dari apa yang sudah digambar dalam program kedalam proses pembangunan. Aspek penerapan ini menjadi hal yang paling optimal dikarenakan peserta merupakan karyawan yang setiap hari berhubungan dengan proyek sehingga memahami penerapan dari gambar kedalam bentuk fisik.

\section{KESIMPULAN}

Berdasarkan hasil dan pembahasan yang telah dijabarkan, dapat ditarik kesimpulan yaitu adanya peningkatan kemampuan dari karyawan kontrak UPT Yosowilangun setelah adanya pelatihan. Kegiatan pelatihan ini juga mendukung social exchange theory sesuai yang diharapkan di awal identifikasi permasalahan. Kemampuan karyawan kontrak dalam menggunakan program autocad sebelum dan sesudah kegiatan pelatihan terjadi peningkatan. Meskipun peningkatan masih belum mancapai optimal namun hasilnya dapat dirasakan oleh pihak organisasi. Ketercapaian keberhasilan dapat diukur dengan aspek kecepatan, ketelitian, pemahaman fitur, dan penerapan.

\section{UCAPAN TERIMA KASIH}

Penulis mengucapkan terima kasih kepada STIE Widya Gama Lumajang yang telah memberikan kesempatan dan dukungan finansial pada kegiatan pengabdian ini. Ucapan terima kasih juga kepada Dinas PUTR Kabupaten Lumajang UPT Yosowilangun yang telah membantu terlaksananya kegiatan. 


\section{DAFTAR PUSTAKA}

de Grip, A., Fouarge, D., Montizaan, R., \& Schreurs, B. (2020). Train to retain: Training opportunities, positive reciprocity, and expected retirement age. Journal of Vocational Behavior, 117, 103332. doi: 10.1016/j.jvb.2019.103332

Dharmawati, Lubis, I., \& Liza, R. (2020). Pembelajaran Berbasis Komputer Menggunakan Ms. Office 2019 Pada Siswa Di Smk Dwitunggal 1 Tanjung Morawa. Dinamisia : Jurnal Pengabdian Kepada Masyarakat, 4(1), 18-25. doi: 10.31849/dinamisia.v4i1.3751

Ishak, \& Mulyanah, E. Y. (2020). Pelatihan Guru Sd Di Tangerang: Implementasi Tpr Dalam Meningkatkan Penguasaan Bahasa Inggris. Dinamisia : Jurnal Pengabdian Kepada Masyarakat, 4(1), 1-5. doi: 10.31849/dinamisia.v4i1.3659

Mishra, P., Bhatnagar, J., Gupta, R., \& Wadsworth, S. M. (2019). How work-family enrichment influence innovative work behavior: Role of psychological capital and supervisory support. Journal of Management \& Organization, 25(1), 58-80. doi: 10.1017/jmo.2017.23

Mokhber, M., Khairuzzaman, W., \& Vakilbashi, A. (2018). Leadership and innovation: The moderator role of organization support for innovative behaviors. Journal of Management \& Organization, 24(1), 108-128. doi: 10.1017/jmo.2017.26

Pham, N. T., Vo-Thanh, T., Shahbaz, M., Duc Huynh, T. L., \& Usman, M. (2020). Managing environmental challenges: Training as a solution to improve employee green performance. $J$ Environ Manage, 269, 110781. doi: 10.1016/j.jenvman.2020.110781

Peraturan Menteri dalam Negeri Republik Indonesia. (2019). Tata Cara Peran Masyarakat Dalam Perencanaan Tata Ruang Di Daerah. Indonesia: Menteri Dalam

Ramadhan, A. (2016). Pelatihan Penggunaan Software AutoCAD Bentuk 3 Dimensi Sebagai Pelengkap Gambar Kerja. Jurnal Abdi Masyarakat (JAM), 2(1), 6-18.

Sandy, B. D. A., Hisyam, E. S., Apriyanti, Y., Gunawan, I., Fikri, M., \& Radiyan. (2020). Pelatihan Aplikasi Data Kependudukan Dan Surat Menyurat Di Desa Jada Bahrin. Dinamisia : Jurnal Pengabdian Kepada Masyarakat, 4(1), 106-112. doi: 10.31849/dinamisia.v4i1.3321

Sok, J., Blomme, R. J., Ruiter, M. D., Tromp, D., \& Lub, X. D. (2018). Home to work spillover and turnover intentions The mediating role of training and development practices. European Journal of Training and Development, 42(3/4), 246-265. doi: 10.1108/EJTD-07-2017-0060

Sulistyan, R. B. (2017). Website Management Training Tourism Village in Sumber Pakel Padang District Lumajang. International Journal of Society Development and Engagement, 1(1), 120128.

Sulistyan, R. B., Ermawati, E., Hidayat, Z., Lukiana, N., \& Kasno. (2019). Retention Management as an Effort to Overcome the Intention of Account Officers to Stop the Company. Journal of Advanced Research in Dynamical and Control Systems, 11(12), 17-25. doi: 10.5373/jardcs/v11i12/20193207

Sulistyan, R. B., Setyobakti, M. H., \& Darmawan, K. (2019). Strategi Pemberdayaan Masyarakat melalui Program Pembentukan Destinasi Wisata dan Usaha Kecil. Empowerment Society, 2(2), $1-7$.

Warman, J. S., Mardian, V., Suryani, L., Fista, F. R., \& Irwan, I. (2019). Program Pelatihan Penigkatan Kemampuan Bahasa Inggris Anak-Anak Panti Asuhan Melalui Pemberdayaan Mahasiswa. Dinamisia : Jurnal Pengabdian Kepada Masyarakat, 3(2), 280-285. doi: 10.31849/dinamisia.v3i2.3304

Wen, J., Huang, S., \& Hou, P. (2019). Emotional intelligence, emotional labor, perceived organizational support, and job satisfaction: A moderated mediation model. International Journal of Hospitality Management, 81, 120-130. doi: 10.1016/j.ijhm.2019.01.009

Yanti, G., Zainuri, \& Megasari, S. W. (2019). Pelatihan Penjadwalan Dengan Ms Project Bagi Penyedia Jasa Konstruksi Di Kota Pekanbaru. Dinamisia : Jurnal Pengabdian Kepada Masyarakat, 3(Special), 125-134. 